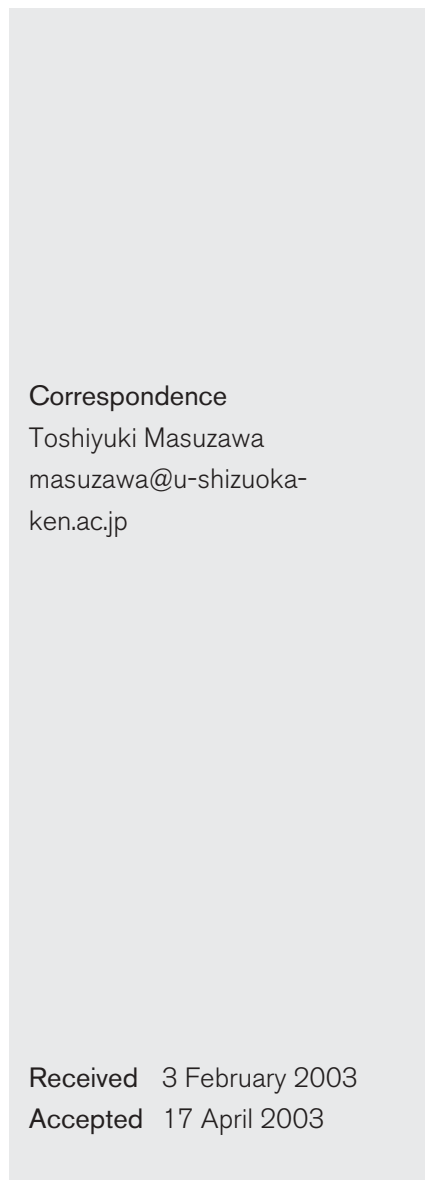

\title{
First isolation and characterization of Borrelia burgdorferi sensu lato strains from Ixodes ricinus ticks in Turkey
}

\author{
Ece S. Güner, ${ }^{1}$ Naoya Hashimoto, ${ }^{2}$ Nobuhiro Takada ${ }^{3}$ Kazuhide Kaneda, ${ }^{2,4}$ \\ Yasuyuki Imai ${ }^{2}$ and Toshiyuki Masuzawa ${ }^{2}$ \\ ${ }^{1}$ Medical School, Yeditepe University, Istanbul, Turkey \\ ${ }^{2}$ Department of Microbiology and COE Program in the 21st Century, University of Shizuoka School of \\ Pharmaceutical Sciences, Shizuoka, Japan \\ ${ }^{3}$ Department of Immunology and Medical Zoology, Fukui Medical University, Matsuoka, Fukui, Japan \\ ${ }^{4}$ Department of Food Science, Shizuoka Eiwa Gakuen University Junior College, Shizuoka, Japan
}

\begin{abstract}
In order to investigate the presence and prevalence of Lyme borreliosis (Lyme disease) Borrelia species, 312 unfed ticks were collected by flagging at a woodland area in Trakya, in the European side of Turkey, in May 2002. Twelve of 299 Ixodes ricinus ticks were infected with Borrelia spp., as determined by cultivation in BSK medium (prevalence rate $4.0 \%$ ). Ten pure cultures were subjected to further characterization by sequencing analysis of the 5S-23S rDNA intergenic spacer, $16 \mathrm{~S}$ rDNA and flagellin gene. One isolate of Borrelia burgdorferi sensu stricto, two of Borrelia garinii (Eurasian type), two of Borrelia afzelii, four of Borrelia lusitaniae and one of Borrelia valaisiana were identified. However, no Asian-type B. garinii was found. Interestingly, all Borrelia species that are known to be carried by I. ricinus were discovered among the 10 isolates. These results provide the first evidence for the existence of the Lyme borreliosis agent in Turkey.
\end{abstract}

\section{INTRODUCTION}

Lyme borreliosis is the most prevalent tick-borne zoonosis in Europe, North America and the Far East (Burgdorfer et al., 1982; Gern et al., 1998; Steere, 2001; Yanagihara \& Masuzawa, 1997). Borrelia burgdorferi (Johnson et al., 1984) sensu lato is classified into 11 species (Masuzawa et al., 2001). In Europe, Ixodes ricinus is the prominent vector tick and transmits five species, B. burgdorferi sensu stricto, Borrelia garinii (Baranton et al., 1992), Borrelia afzelii (Canica et al., 1993), Borrelia lusitaniae (Le Fleche et al., 1997) and Borrelia valaisiana (Wang et al., 1997). Of these five species, B. burgdorferi, B. afzelii and B. garinii are pathogenic to humans. On the other hand, the pathogenicity of $B$. lusitaniae and $B$. valaisiana remains to be elucidated (Escudero et al., 2000; Wang et al., 1999). B. burgdorferi has been isolated and identified in Europe from the vector tick, I. ricinus, wild mammals and patients, in contrast to Turkey, a country that constitutes a bridge between Europe and Asia. Based on RFLP analysis of the 5S-23S rRNA gene spacer, B. garinii were further classified into two subtypes, Eurasian type and

The GenBank/EMBL/DDBJ accession numbers for sequences of rRNA intergenic spacers, flagellin genes and 16S rDNA from Borrelia strains isolated in Turkey are AB091795-AB091804, AB091805-AB091814 and AB091815-AB091824.
Asian type. Eurasian-type B. garinii is found in both Europe and Asia; on the other hand, the Asian type is distributed only in east-Asian countries. Ixodes persulcatus is the vector of the Lyme disease borreliae B. garinii (Eurasian and Asian types) and B. afzelii in Asian countries such as Japan (Masuzawa et al., 1991, 1996a), far-eastern Russia (Masuzawa et al., 1997; Postic et al., 1997; Sato et al., 1996), north-eastern China (Li et al., 1998; Takada et al., 1998), western China (Uighur; Takada et al., 2001b) and Korea (T. Masuzawa, K. H. Park and M. K. Cho, unpublished). Borrelia strains genetically related to B. valaisiana found in Europe are distributed in the southern part of Asia, on Okinawa island, the southernmost islands of Japan (Takada et al., 2001a), Taiwan (Masuzawa et al., 2000), the southern part of China (Masuzawa et al., 2001) and Korea (Masuzawa et al., 1999).

The aims of this study were to isolate B. burgdorferi sensu lato from ticks and to identify the vector tick species on the Black Sea coast of the European side of Turkey, in the Trakya region, and to verify the transmission of Borrelia species, especially $B$. valaisiana and B. garinii (Asian type), from Asia to Europe.

\section{METHODS}

Survey area and tick collection. Unfed adult ticks were collected during May 2002 from vegetation with $1 \mathrm{~m}^{2}$ flannel flags at areas in 
Trakya, including a recreational park (Zekeriyakoy, Belgrad Forest) in the Istanbul metropolitan area (Fig. 1). The habitat in this area contained four main zones of vegetation: (i) woods (such as poplar, oak, acacia, oleander bushes, elm and willow), (ii) high shrub (1 m or taller), (iii) low shrub and (iv) leaf and/or grass litter cover. In Trakya, some of the river banks and delta regions on the Black Sea coast are filled with sand and pebbles that lead to the formation of small lagoons and swamps covered with very dense 'langoz forests'. In some parts, thick forests (such as beech and hornbeam) start at the shore and oak forests cover the mountain valleys (such as Ylldiz mountain, with an altitude of $1031 \mathrm{~m}$ ) away from the marine-type climatic conditions. Edirne and inland Trakya have continental-type climates with less precipitation and vegetation cover. Therefore, tick populations are sparse away from the shore. Temperatures average a maximum of $26-29^{\circ} \mathrm{C}$ (Istanbul area and Black Sea coast) and $29-32^{\circ} \mathrm{C}$ (Edirne and Kurklareli area) and a minimum of $5-10^{\circ} \mathrm{C}$. Temperatures measured during the expedition were $1.5{ }^{\circ} \mathrm{C}$ above the mean value of the last 50 years. Precipitation was within normal values in the expedition area during our study $(800-1000$ $\mathrm{mm} \mathrm{m}^{-2}$ year $^{-1}$ in Istanbul and the Black Sea coast and 550-680 mm $\mathrm{m}^{-2}$ year $^{-1}$ in Edirne and Kirklareli).

Isolation of Borrelia strains. A total of 312 unfed ticks collected from vegetation were dissected under the stereoscopic microscope and internal organs were transferred into BSK II medium (Barbour et al., 1984) and incubated at $33^{\circ} \mathrm{C}$ for 3 months as described by Takada et al. (1998).

Genotyping: rrf-rrl rDNA intergenic spacer, 165 rDNA and flagellin gene sequences. Aliquots $(0.5 \mathrm{ml})$ of cultures were washed and cells were resuspended in $100 \mu \mathrm{l}$ water. The resultant cell suspensions were boiled at $100{ }^{\circ} \mathrm{C}$ for $10 \mathrm{~min}$. PCR was performed by the method of Masuzawa et al. (1996b). Primers corresponding to the $3^{\prime}$ end of the $5 \mathrm{~S}$ rDNA ( $r r f)\left(5^{\prime}\right.$-CTGCGAGTTCGCGGGAGA-3') and the $5^{\prime}$ end of the 23S rDNA ( $\left.r r\right)$ ( $5^{\prime}$-TCCTAGGCATTCACCATA- $3^{\prime}$ ) (Postic et al., 1994) were synthesized by a custom oligonucleotidesynthesis service (Lifetec Oriental Co.). The $16 \mathrm{~S}$ rDNA and the flagellin gene of isolates were amplified with the primers 16SMF, corresponding to the $5^{\prime}$ end of the $16 \mathrm{~S}$ rDNA (5'-GCGAACGGGTGAGTAACG-3'), and 16SMR, corresponding to the $3^{\prime}$ end of $16 \mathrm{~S}$ rDNA $\left(5^{\prime}-\right.$ CCTCCCTTACGGGTTAGAA- $3^{\prime}$ ), and primers A, corresponding to the $5^{\prime}$ end of $f l a\left(5^{\prime}\right.$-TCTGATGATGCTGCTGCTGGTATGG-3'), and $\mathrm{D}$, corresponding to the $3^{\prime}$ end of fla (5'-TCCAAAAGTTATCGTAT GAG-3'). Amplicons from the intergenic spacer sequence (about $250 \mathrm{bp}$ ), the flagellin gene (about $750 \mathrm{bp}$ ) and the 16S rDNA (about 1360 bp) were purified with DNA purification columns (MicroconPCR; Millipore). DNA cycle-sequencing was performed by using a Thermo Sequenase pre-mixed cycle-sequencing kit (Amersham) according to the manufacturer's recommendation. DNA sequences were determined by using a model SQ5500EL DNA sequencer (Hitachi). Based on the determined DNA sequence of the amplicon, RFLP analysis of the 5S-23S rDNA intergenic spacer was determined by using Genetyx-Mac software (Hitachi).

Phylogenetic analysis. CLUSTALX (Thompson et al., 1997) was used to align the sequences and phylogenetic distances were calculated using the neighbour-joining method (Saitou \& Nei, 1987). The phylogenetic tree was drawn using N-J plot software. Bootstrap values were obtained from 1000 resamplings.

\section{RESULTS AND DISCUSSION}

\section{Isolation of Borrelia strains}

We examined 312 unfed ticks from four different species (I. ricinus, Rhipicephalus haemaphysaloides, Haemaphysalis aponommoides and Ixodes sp. near turdus), and 12 (three from nymphs, four from adult males and five from adult females) of 299 I. ricinus ticks were positive for spirochaetes by dark-field microscopy (Table 1). All spirochaetes were isolated from $I$. ricinus, rather than from other tick species. Overall, the prevalence rate was $4.0 \%$. The infection rate among $I$. ricinus was highest in Langoz $(16 \cdot 6 \%)$. The prevalence rate in our survey area is relatively lower than rates found in Bulgaria (17\% by culture and more than $30 \%$ by PCR; Christova et al., 1998, 2001). Incidence of Lyme borreliosis in Central European countries such as Slovenia and Austria is relatively higher and it gradually decreases

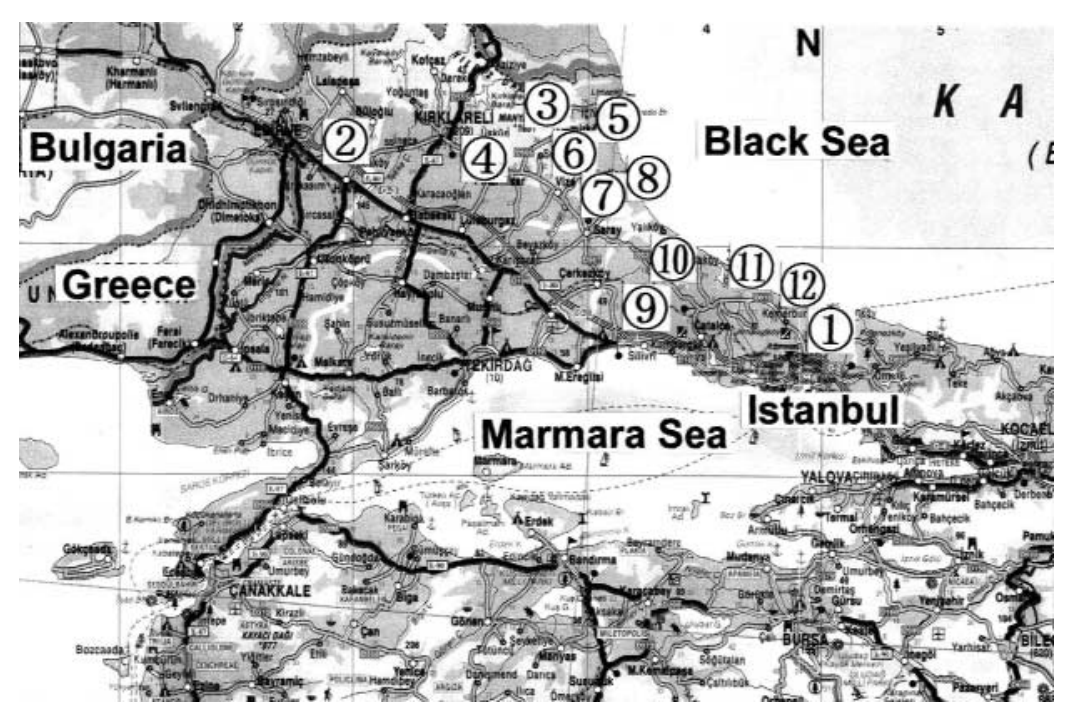

Fig. 1. Collection site of vector ticks in Trakya, in the European part of Turkey. Numbers denote expedition areas: 1, Zekeriyakoy; 2 , Edirne; 3, Demirkoy; 4, Yenice; 5, Langoz; 6, Sivriler; 7, Hamidiye; 8, Kiyikoy; 9, Danamandira; 10, Karamandere; 11, Ormanli; 12, Kemerburgaz. Original scale: 1:2000 000. Reproduced by kind permission of İki Nokta, Istanbul. 
Table 1. Isolation and identification of Lyme disease-related Borrelia strains

\begin{tabular}{|c|c|c|c|c|}
\hline \multirow[t]{2}{*}{ Site } & \multirow[t]{2}{*}{ Location } & \multicolumn{2}{|c|}{ Ticks infected/examined (prevalence, $\%$ ) } & \multirow{2}{*}{ Isolates (tick developmental stage) $\dagger$} \\
\hline & & I. ricinus & Other species ${ }^{\star}$ & \\
\hline 1 & Zekeriyakoy & $2 / 41(4 \cdot 9)$ & - & $\operatorname{Tr} 29(\mathrm{M}), \operatorname{Tr} 38(\mathrm{M})$ \\
\hline 2 & Edirne & - & $0 / 1(0)^{a}$ & \\
\hline 3 & Demirkoy & $2 / 102(2 \cdot 0)$ & - & $\operatorname{Tr} 77(\mathrm{~N}), \operatorname{Tr} 96(\mathrm{~N})$ \\
\hline 4 & Yenice & $0 / 9(0)$ & $0 / 1(0)^{a}$ & \\
\hline 5 & Langoz & $2 / 12(16 \cdot 6)$ & $0 / 7(0)^{b}$ & $\operatorname{Tr} 161(\mathrm{~F}), \operatorname{Tr} 170(\mathrm{~F})$ \\
\hline 6 & Sivriler & $3 / 41(7 \cdot 3)$ & $0 / 3(0)^{b}$ & $\operatorname{Tr} 210(\mathrm{~F}), \operatorname{Tr} 213(\mathrm{M}), \mathrm{ND}(\mathrm{F})$ \\
\hline 7 & Hamidiye & $1 / 37(2 \cdot 7)$ & - & $\mathrm{ND}(\mathrm{M})$ \\
\hline 8 & Kiyikoy & $0 / 20(0)$ & - & \\
\hline 9 & Danamandira & $0 / 7(0)$ & - & \\
\hline 10 & Karamandere & $1 / 20(5 \cdot 0)$ & $0 / 1(0)^{c}$ & $\operatorname{Tr} 293(\mathrm{~N})$ \\
\hline 11 & Ormanli & $1 / 8(12 \cdot 5)$ & - & $\operatorname{Tr} 309(\mathrm{~F})$ \\
\hline \multirow[t]{2}{*}{12} & Kemerburgaz & $0 / 2(0)$ & - & \\
\hline & Total & $12 / 299(4 \cdot 0)$ & $0 / 13(0)$ & \\
\hline
\end{tabular}

${ }^{\star}$ Other tick species are indicated as: $a$, Rhipicephalus haemaphysaloides; $b$, Haemaphysalis aponommoides; $c$, Ixodes sp. near turdus.

$\dagger$ Tick developmental stages from which isolates were obtained are abbreviated as: N, nymph; M, adult male; F, adult female. ND, Culture positive, but did not grow well in BSK II medium.

from north to south. The annual incidence of Lyme borreliosis in Bulgaria (55.0/100000) is relatively high among European countries (O’Connell et al., 1998). On the other hand, a seroepidemiological survey done in Greece among 1100 male navy recruits showed that only three of the serum samples were positive for B. burgdorferi antibodies $(0.27 \%)$ (Stamouli et al., 2000). The prevalence in Tunisia was $34 \%$ by PCR and $5 \%$ by BSK culture in adult I. ricinus ticks (Younsi et al., 2001). These reports support our observation that the estimated prevalence rates in Turkey, as determined by cultivation in BSK medium, are within the range of values expected.

\section{Species determination based on 5S-23S rDNA intergenic spacer sequence}

Ten of the 12 pure cultures were subjected to further genotyping analyses. All of them amplified about a $250 \mathrm{bp}$ DNA amplicon with the intergenic spacer PCR system. Based on the DNA sequence of the amplicon, the RFLP pattern of the 5S-23S rDNA intergenic spacer was determined (Table 2). Strains $\operatorname{Tr} 161, \operatorname{Tr} 210$ and $\operatorname{Tr} 213$ showed RFLP patterns similar to that of $B$. lusitaniae PotiB2 ${ }^{\mathrm{T}}$ from $I$. ricinus (Postic et al., 1994). Strain Tr170, identified as B. lusitaniae, generated a different RFLP pattern from that of strain PotiB2 ${ }^{\mathrm{T}}$ because of the presence of an extra restriction site. Strain Tr293 generated restriction fragments similar to those of B. burgdorferi $\mathrm{B} 31^{\mathrm{T}}$. The DraI RFLP pattern of strain Tr29 was identical to strain VS116 ${ }^{\mathrm{T}}$, the type strain of B. valaisiana, but the MseI pattern was different because of the absence of two sites. Strains Tr38 and Tr96 and strains Tr77 and Tr309 respectively had identical RFLP patterns to $B$. afzelii VS461 ${ }^{\mathrm{T}}$ and $B$. garinii $20047^{\mathrm{T}}$. However, none of the strains showed RFLP patterns similar to those of Asian-type B. garinii ASF (NT29 type) (Li et al., 1998; Masuzawa et al., 1997; Miyamoto \& Masuzawa, 2002; Postic et al., 1994).

These strains clustered with representative strains of each species in the phylogenetic tree (Fig. 2). Strains from Turkey showed the following sequence similarity for the 5S-23S rDNA intergenic spacer sequences: $97 \cdot 3 \%$ for $\operatorname{Tr} 29$ and $B$. valaisiana VS116 ${ }^{\mathrm{T}}, 99.6$ and $97.6 \%$ respectively for $\operatorname{Tr} 38$ and Tr96 with B. afzelii VS461 ${ }^{\mathrm{T}}, 100$ and $98.8 \%$ respectively for Tr77 and Tr309 with B. garinii $20047^{\mathrm{T}}$ and $97 \cdot 2 \%$ for Tr293 and B. burgdorferi $\mathrm{B} 31^{\mathrm{T}}$. Strains $\operatorname{Tr} 161, \operatorname{Tr} 170, \operatorname{Tr} 210$ and $\operatorname{Tr} 213$ showed more similarity to $B$. lusitaniae PotiB2 ${ }^{\mathrm{T}}$, ranging from $94 \cdot 6$ to $97 \cdot 3 \%$. From these results, one isolate of $B$. burgdorferi sensu stricto, two of $B$. garinii (Eurasian type), two of $B$. afzelii, four of $B$. lusitaniae and one of $B$. valaisiana were identified; however, no Asian-type B. garinii was found.

\section{Sequence similarity of flagellin genes and 165 rDNA}

Figs 3 and 4 show phylogenetic trees constructed on the basis of flagellin gene and 16S rDNA sequences. Strains Tr161, $\operatorname{Tr} 170$, Tr210 and Tr213 showed more similarity for partial sequences of the flagellin gene to B. lusitaniae strain PotiB2 ${ }^{\mathrm{T}}$ (98.5-99.3 \%). Strain Tr38 and Tr96, identified as B. afzelii, showed sequences identical to that of B. afzelii VS461 ${ }^{\mathrm{T}}$. Strain Tr77 and Tr309 showed higher similarity to B. garinii $20047^{\mathrm{T}}$ (European type), isolated from $I$. ricinus in France, than to $B$. 
Table 2. RFLP analysis of the $5 S-23 S$ rDNA intergenic spacer

Species assignments of Turkish isolates were determined in this study. Exact restriction fragment sizes were determined from sequences.

\begin{tabular}{|c|c|c|c|c|}
\hline \multirow[t]{2}{*}{ Strain } & \multirow{2}{*}{$\begin{array}{l}\text { Amplicon } \\
\text { (bp) }\end{array}$} & \multicolumn{2}{|c|}{ Restriction fragments (bp) } & \multirow[t]{2}{*}{ Species } \\
\hline & & DraI & MseI & \\
\hline \multicolumn{5}{|l|}{ Turkish isolates } \\
\hline $\operatorname{Tr} 29$ & 255 & 203,52 & 204,51 & B. valaisiana \\
\hline $\operatorname{Tr} 38$ & 246 & $174,52,20$ & $107,68,51,20$ & B. afzelii \\
\hline $\operatorname{Tr} 77$ & 253 & 201,52 & $107,95,51$ & B. garinii \\
\hline $\operatorname{Tr} 96$ & 246 & $174,52,20$ & $107,68,51,20$ & B. afzelii \\
\hline $\operatorname{Tr} 161$ & 256 & $145,82,29$ & $107,81,39,29$ & B. lusitaniae \\
\hline $\operatorname{Tr} 170$ & 257 & $146,53,29,29$ & $107,52,40,29,29$ & B. lusitaniae \\
\hline $\operatorname{Tr} 210$ & 256 & $145,82,29$ & $107,81,39,29$ & B. lusitaniae \\
\hline $\operatorname{Tr} 213$ & 256 & $145,82,29$ & $107,81,39,29$ & B. lusitaniae \\
\hline $\operatorname{Tr} 293$ & 256 & $146,53,29,28$ & $107,52,40,29,28$ & B. burgdorferi \\
\hline $\operatorname{Tr} 309$ & 253 & 201,52 & $107,95,51$ & B. garinii \\
\hline \multicolumn{5}{|l|}{ Reference strains } \\
\hline B. burgdorferi $\mathrm{B} 31^{\mathrm{T}}$ & 254 & $144,53,29,28$ & $108,51,38,29,28$ & \\
\hline B. garinii $20047^{\mathrm{T}}$ (Eurasia) & 253 & 201,52 & $107,95,51$ & \\
\hline B. garinii ASF (Asia) & 253 & $144,57,52$ & $107,57,51,38$ & \\
\hline B. afzelii VS461 ${ }^{\mathrm{T}}$ & 246 & $174,52,20$ & $107,68,51,20$ & \\
\hline B. lusitaniae PotiB2 ${ }^{\mathrm{T}}$ & 257 & $145,83,29$ & $107,82,39,29$ & \\
\hline B. lusitaniae PotiB3 & 255 & $158,81,16$ & $108,79,52,16$ & \\
\hline B. valaisiana $\mathrm{VS}_{116^{\mathrm{T}}}$ & 255 & 203,52 & $174,51,23,7$ & \\
\hline
\end{tabular}

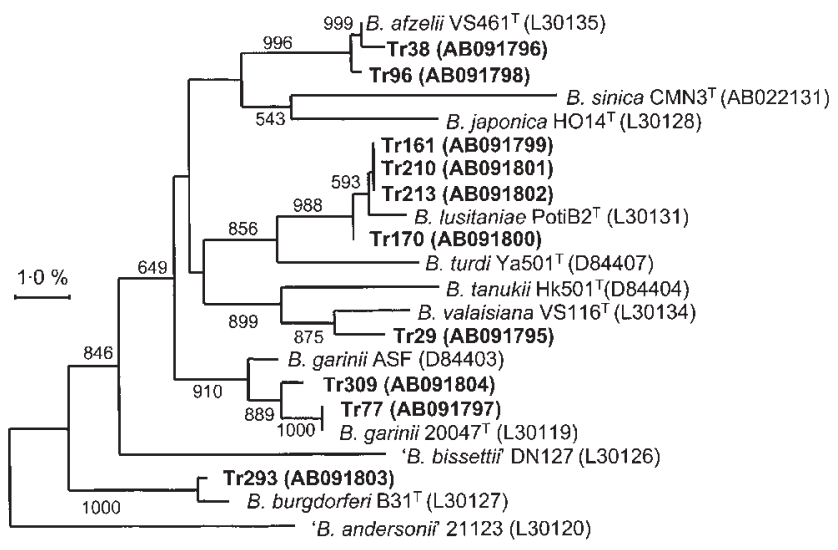

Fig. 2. Phylogenetic tree based on the $5 S-23 S$ rRNA intergenic spacer sequence. Accession numbers are shown in parentheses. Bar, $1.0 \%$ sequence divergence. Isolates from Turkey are in bold.

garinii HT22 (Asian type), isolated from I. persulcatus in Japan. On the phylogenetic tree constructed from $16 \mathrm{~S}$ rDNA sequences, the sequences of all isolates in Turkey clustered with those of strains of each species, indicating the accuracy of species determination. Five Borrelia species, B. burgdorferi, B. garinii, B. afzelii, B. valaisiana and B. lusitaniae, that are

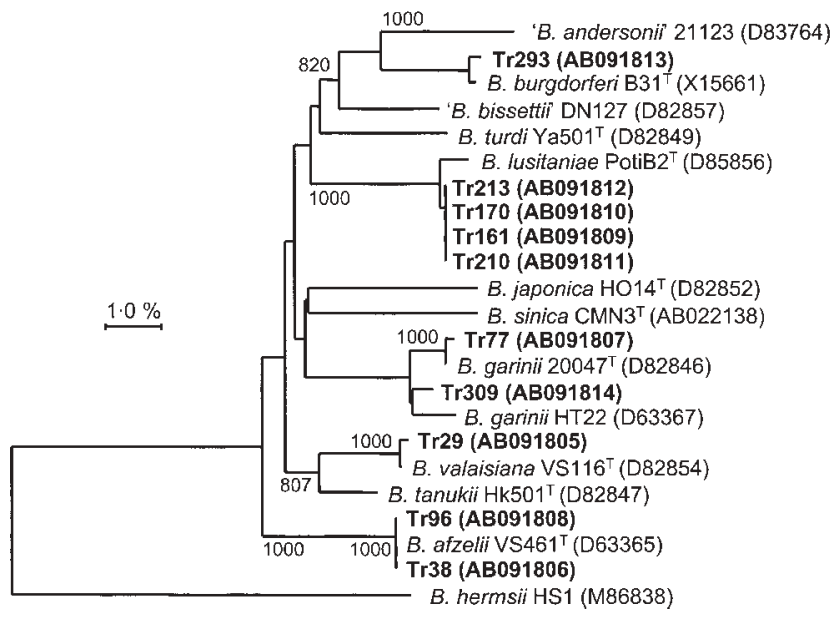

Fig. 3. Phylogenetic tree based on the flagellin gene sequence. Accession numbers are shown in parentheses. Bar, $1.0 \%$ sequence divergence. Isolates from Turkey are in bold.

known to be transmitted by I. ricinus (Wang et al., 1999) were found among 10 Turkish isolates. The genetic heterogeneity and differences found between other European isolates were not detected in the Turkish isolates. Interestingly, all five Borrelia species that can be transmitted by I. ricinus have 


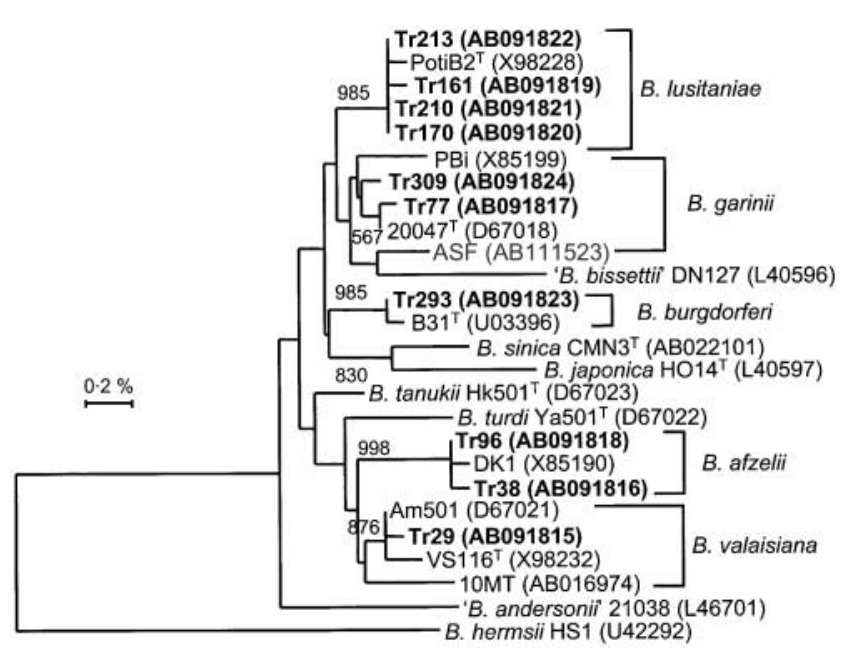

Fig. 4. Phylogenetic tree based on the $16 \mathrm{~S}$ rRNA gene sequence. Accession numbers are shown in parentheses. Bar, $0.2 \%$ sequence divergence. Isolates from Turkey are in bold. The sequence of $B$. garinii ASF was also determined in this study.

never been isolated from such a limited area, which makes this distribution unique. Regarding the distribution of B. lusitaniae, a few strains have been found in Spain (Barral et al., 2002; Escudero et al., 2000), Portugal (De Michelis et al., 2000), Slovakia (Gern et al., 1999), the Czech Republic, Moldova and Ukraine (Postic et al., 1997), Tunisia (Younsi et al., 2001; Zhioua et al., 1999), Poland (Mizak \& Krol, 2000) and Switzerland (L. Gern, personal communication). Most of the isolates found in Tunisia and Portugal were identified as B. lusitaniae. This terrestrial distribution indicates that this species has been maintained by a narrow range of reservoir host species inhabiting the southern part of the Northern hemisphere, around the Mediterranean Basin (De Michelis et al., 2000). This led us to speculate that the transmission and proliferation of this type of borrelia occurred between I. ricinus and some animals that inhabit Southern Europe and which serve as reservoir hosts for Borrelia species. On the other hand, B. garinii and B. afzelii are frequently isolated in Germany, France and Russia (Wang et al., 1999). B. valaisiana is found in I. ricinus and avian reservoirs from the UK (Kurtenbach et al., 1998), Ireland (Gray et al., 2000; Kirstein et al., 1997), The Netherlands (Rijpkema et al., 1996b), Switzerland (Peter \& Bretz, 1992), Germany (Liebisch et al., 1998), Italy (Cinco et al., 1998), Croatia (Rijpkema et al., 1996a), the Czech Republic (Postic et al., 1997), Slovakia (Gern et al., 1999) and Bulgaria (Christova et al., 2001). B. burgdorferi sensu stricto isolates are mostly found in Western Europe (Wang et al., 1999).

It has been speculated that the genospecies diversity of $B$. burgdorferi sensu lato decreases towards the southern margin of its European range (De Michelis et al., 2000; Wang et al., 1999). There is one report in which DNA of five different Borrelia species was found in I. ricinus ticks collected in a wooded area near Sofia, Bulgaria (Christova et al., 2001); however, spirochaetes were not isolated from these ticks. This is the first report of isolation of Lyme borreliae in Turkey and, moreover, the isolation of five different Borrelia species from $I$. ricinus ticks collected from a very limited area in Europe. This finding may suggest that there is a substantial ecological niche occupied by I. ricinus in the ecosystem of Trakya.

Fewer than 20 Lyme borreliosis cases have been published in Turkey since 1990 (Aksu et al., 1997; Bil, 1998; Cakir et al., 1990; Ergul et al., 1996; Koksal et al., 1990; Leblebicioglu, 1999; Ozturk et al., 1996). These cases were diagnosed as Lyme borreliosis based on clinical symptoms such as arthralgia, myalgia, extreme fatigue, migratory pain, erythema migrans and positive IgG-ELISA results with antigens derived from European isolates. To our knowledge, there are no reports of Borrelia isolates from patients in Turkey, so Borrelia strains have not been isolated from either the patients addressed or from others. The authors conclude that case-control studies would be necessary in order for physicians to become more interested in Lyme borreliosis. Further risk assessment for Lyme borreliosis is important, especially in the Zekeriyakoy-Belgrad Forest region, since it is one of the most popular recreational parks of the Istanbul metropolitan area.

In conclusion, our results prove, for the first time, the existence of Lyme borreliosis agent in I. ricinus ticks collected in the European part of Turkey.

\section{ACKNOWLEDGEMENTS}

We thank Drs L. Gern (Switzerland) and M. Collares-Pereira (Portugal) for providing information on the distribution of B. lusitaniae in Europe. We also thank Mr Kor Sen for his help during our expedition. This study was supported in part by Grants-in-Aid for Scientific Research (B) no. 13576014 from the Japan Society for the Promotion of Science (JSPS).

\section{REFERENCES}

Aksu, M., Soyak, O., Arman, F., Elmas, O. \& Demir, H. (1997). A Lyme disease case presented with encephalomyelitis. JCukurova Med School 2, 145-148 (in Turkish).

Baranton, G., Postic, D., Saint Girons, I., Boerlin, P., Piffaretti, J.-C., Assous, M. \& Grimont, P. A. D. (1992). Delineation of Borrelia burgdorferi sensu stricto, Borrelia garinii sp. nov., and group VS461 associated with Lyme borreliosis. Int J Syst Bacteriol 42, 378-383.

Barbour, A. G. (1984). Isolation and cultivation of Lyme disease spirochetes. Yale J Biol Med 57, 521-525.

Barral, M., Garcia-Perez, A. L., Juste, R. A., Hurtado, A., Escudero, R., Sellek, R. E. \& Anda, P. (2002). Distribution of Borrelia burgdorferi sensu lato in Ixodes ricinus (Acari: Ixodidae) ticks from the Basque Country, Spain. J Med Entomol 39, 177-184.

Bil, N. (1998). Lyme disease causing meningoencephalitis. J Neurol Sci 15, 13-21 (in Turkish).

Burgdorfer, W., Barbour, A. G., Hayes, S. F., Benach, J. L., Grunwaldt, E. \& Davis, J. P. (1982). Lyme disease - a tick-borne spirochetosis? Science 216, 1317-1319.

Cakir, N., Akandere, Y., Hekim, N, Kovanci, E. \& Yazici, H (1990). Two Lyme disease cases. J Clin Proc 4, 839-841 (in Turkish). 
Canica, M. M., Nato, F., du Merle, L., Mazie, J. C., Baranton, G. \& Postic, D. (1993). Monoclonal antibodies for identification of Borrelia afzelii sp. nov. associated with late cutaneous manifestations of Lyme borreliosis. Scand J Infect Dis 25, 441-448.

Christova, I., Hohenberger, S., Zehetmeier, C. \& Wilske, B. (1998). First characterization of Borrelia burgdorferi sensu lato from ticks and skin biopsy in Bulgaria. Med Microbiol Immunol 186, 171-175.

Christova, I., Schouls, L., van de Pol, I., Park, J., Panayotov, S., Lefterova, V., Kantardjiev, T. \& Dumler, J. S. (2001). High prevalence of granulocytic Ehrlichiae and Borrelia burgdorferi sensu lato in Ixodes ricinus ticks from Bulgaria. J Clin Microbiol 39, 4172-4174.

Cinco, M., Padovan, D., Murgia, R., Poldini, L., Frusteri, L., van de Pol, I., Verbeek-De Kruif N., Rijpkema, S. \& Maroli, M. (1998). Rate of infection of Ixodes ricinus ticks with Borrelia burgdorferi sensu stricto, Borrelia garinii, Borrelia afzelii and group VS116 in an endemic focus of Lyme disease in Italy. Eur J Clin Microbiol Infect Dis 17, 90-94.

De Michelis, S., Sewell, H. S., Collares-Pereira, M., Santos-Reis, M., Schouls, L. M., Benes, V., Holmes, E. C. \& Kurtenbach, K. (2000). Genetic diversity of Borrelia burgdorferi sensu lato in ticks from mainland Portugal. J Clin Microbiol 38, 2128-2133.

Ergul, E., Ozer, S., Ogutman, R., Hakko, M., Kara, M. \& Uzun, K. (1996). Two Lyme disease cases. In Abstracts of the 27th Turkish Society of Microbiology Conference, 01:P-57. Antalya (in Turkish).

Escudero, R., Barral, M., Perez, A., Vitutia, M. M., Garcia-Perez, A. L., Jimenez, S., Sellek, R. E. \& Anda, P. (2000). Molecular and pathogenic characterization of Borrelia burgdorferi sensu lato isolates from Spain. J Clin Microbiol 38, 4026-4033.

Gern, L., Estrada-Pena, A., Frandsen, F. \& 7 other authors (1998). European reservoir hosts of Borrelia burgdorferi sensu lato. Zentbl Bakteriol 287, 196-204.

Gern, L., Hu, C. M., Kocianova, E., Vyrostekova, V. \& Rehacek, J. (1999). Genetic diversity of Borrelia burgdorferi sensu lato isolates obtained from Ixodes ricinus ticks collected in Slovakia. Eur J Epidemiol 15, $665-669$.

Gray, J. S., Robertson, J. N. \& Key, S. (2000). Limited role of rodents as reservoirs of Borrelia burgdorferi sensu lato in Ireland. Eur J Epidemiol 16, 101-103.

Johnson, R. C., Schmid, G. P., Hyde, F. W., Steigerwalt, A. G. \& Brenner, D. J. (1984). Borrelia burgdorferi sp. nov.: etiologic agent of Lyme disease. Int J Syst Bacteriol 34, 496-497.

Kirstein, F., Rijpkema, S., Molkenboer, M. \& Gray, J. S. (1997). The distribution and prevalence of B. burgdorferi genomospecies in Ixodes ricinus ticks in Ireland. Eur J Epidemiol 13, 67-72.

Koksal, I., Saltoglu, N., Bingul, T. \& Ozturk, H. (1990). Two Lyme disease case reports. J Ankem 4, 284 (in Turkish).

Kurtenbach, K., Peacey, M., Rijpkema, S. G., Hoodless, A. N., Nuttall, P. A. \& Randolph, S. E. (1998). Differential transmission of the genospecies of Borrelia burgdorferi sensu lato by game birds and small rodents in England. Appl Environ Microbiol 64, 1169-1174.

Leblebicioglu, H. (1999). A Lyme disease case presented with CNS symptoms. In Abstracts of the 4th Medical Imaging and Radiology Conference. Antalya (in Turkish).

Le Fleche, A., Postic, D., Girardet, K., Peter, O. \& Baranton, G. (1997). Characterization of Borrelia lusitaniae sp. nov. by $16 \mathrm{~S}$ ribosomal DNA sequence analysis. Int J Syst Bacteriol 47, 921-925.

Li, M., Masuzawa, T., Takada, N. \& 7 other authors (1998). Lyme disease Borrelia species in northeastern China resemble those isolated from far eastern Russia and Japan. Appl Environ Microbiol 64, 2705-2709.

Liebisch, G., Sohns, B. \& Bautsch, W. (1998). Detection and typing of Borrelia burgdorferi sensu lato in Ixodes ricinus ticks attached to human skin by PCR. J Clin Microbiol 36, 3355-3358.
Masuzawa, T., Okada, Y., Yanagihara, Y. \& Sato, N. (1991). Antigenic properties of Borrelia burgdorferi isolated from Ixodes ovatus and Ixodes persulcatus in Hokkaido, Japan. J Clin Microbiol 29, 1568-1573.

Masuzawa, T., Wilske, B., Komikado, T. \& 9 other authors (1996a). Comparison of OspA serotypes for Borrelia burgdorferi sensu lato from Japan, Europe and North America. Microbiol Immunol 40, 539-545.

Masuzawa, T., Komikado, T., Iwaki, A., Suzuki, H., Kaneda, K. \& Yanagihara, Y. (1996b). Characterization of Borrelia sp. isolated from Ixodes tanuki, I. turdus, and I. columnae in Japan by restriction fragment length polymorphism of $r r f(5 S)-r r l(23 S)$ intergenic spacer amplicons. FEMS Microbiol Lett 142, 77-83.

Masuzawa, T., Iwaki, A., Sato, Y., Miyamoto, K., Korenberg, E. I. \& Yanagihara, Y. (1997). Genetic diversity of Borrelia burgdorferi sensu lato isolated in far eastern Russia. Microbiol Immunol 41, 595-600.

Masuzawa, T., Fukui, T., Miyake, M., Oh, H.-B., Cho, M.-K., Chang, W.-H., Imai, Y. \& Yanagihara, Y. (1999). Determination of members of a Borrelia afzelii-related group isolated from Ixodes nipponensis in Korea as Borrelia valaisiana. Int J Syst Bacteriol 49, 1409-1415.

Masuzawa, T., Pan, M. J., Kadosaka, T., Kudeken, M., Takada, N., Yano, Y., Imai, Y. \& Yanagihara, Y. (2000). Characterization and identification of Borrelia isolates as Borrelia valaisiana in Taiwan and Kinmen Islands. Microbiol Immunol 44, 1003-1009.

Masuzawa, T., Takada, N., Kudeken, M., Fukui, T., Yano, Y., Ishiguro, F., Kawamura, Y., Imai, Y. \& Ezaki, T. (2001). Borrelia sinica sp. nov., a Lyme disease-related Borrelia species isolated in China. Int J Syst Evol Microbiol 51, 1817-1824.

Miyamoto, K. \& Masuzawa, T. (2002). Ecology of Borrelia burgdorferi sensu lato in Japan and East Asia. In Lyme Borreliosis: Biology and Control, pp. 201-222. Edited by J. Gray, O. Kahl, R. S. Lane \& G. Stanek. Wallingford, UK: CABI.

Mizak, B. \& Krol, J. (2000). Analysis of Polish isolates of Borrelia burgdorferi by amplification of $r r f(5 S)-r r l(23 S)$ intergenic spacer. Bull Vet Inst Pulawy 44, 147-154.

O'Connell, S., Granstrom, M., Gray, J. S. \& Stanek, G. (1998). Epidemiology of European Lyme borreliosis. Zentbl Bakteriol 287, 229-240.

Ozturk, R., Mert, A., Basaran, G. \& Ergin, S. (1996). A Lyme disease case. In Abstracts of the 27th Turkish Society of Microbiology Conference, 01:P59. Antalya (in Turkish).

Peter, O. \& Bretz, A. G. (1992). Polymorphism of outer surface proteins of Borrelia burgdorferi as a tool for classification. Zentbl Bakteriol 277, 28-33.

Postic, D., Assous, M. V., Grimont, P. A. D. \& Baranton, G. (1994). Diversity of Borrelia burgdorferi sensu lato evidenced by restriction fragment length polymorphism of $r r f(5 S)$ - $r r l$ (23S) intergenic spacer amplicons. Int J Syst Bacteriol 44, 743-752.

Postic, D., Korenberg, E., Gorelova, N., Kovalevski, Y. V., Bellenger, E. \& Baranton, G. (1997). Borrelia burgdorferi sensu lato in Russia and neighbouring countries: high incidence of mixed isolates. Res Microbiol 148, 691-702.

Rijpkema, S., Golubic, D., Molkenboer, M., Verbeek-De Kruif, N. \& Schellekens, J. (1996a). Identification of four genomic groups of Borrelia burgdorferi sensu lato in Ixodes ricinus ticks collected in a Lyme borreliosis endemic region of northern Croatia. Exp Appl Acarol 20, $23-30$.

Rijpkema, S. G., Herbes, R. G., Verbeek-De Kruif, N. \& Schellekens, J. F. (1996b). Detection of four species of Borrelia burgdorferi sensu lato in Ixodes ricinus ticks collected from roe deer (Capreolus capreolus) in The Netherlands. Epidemiol Infect 117, 563-566.

Saitou, N. \& Nei, M. (1987). The neighbor-joining method: a new method for reconstructing phylogenetic trees. Mol Biol Evol 4, 406-425. 
Sato, Y., Miyamoto, K., Iwaki, A. \& 7 other authors (1996). Prevalence of Lyme disease spirochetes in Ixodes persulcatus and wild rodents in far eastern Russia. Appl Environ Microbiol 62, 3887-3889.

Stamouli, M., Totos, G., Braun, H. B., Michel, G. \& Gizaris, V. (2000). Very low seroprevalence of Lyme borreliosis in young Greek males. Eur J Epidemiol 16, 495-496.

Steere, A. C. (2001). Lyme disease. N Engl J Med 345, 115-125.

Takada, N., Ishiguro, F., Fujita, H., Wang, H. P., Wang, J. C. \& Masuzawa, T. (1998). Lyme disease spirochetes in ticks from northeastern China. J Parasitol 84, 499-504.

Takada, N., Fujita, H., Yano, Y., Ishiguro, F., Iwasaki, H. \& Masuzawa, T. (2001a). First records of tick-borne pathogens, Borrelia, and spotted fever group rickettsiae in Okinawajima Island, Japan. Microbiol Immunol 45, 163-165.

Takada, N., Masuzawa, T., Ishiguro, F. \& 7 other authors (2001b). Lyme disease Borrelia spp. in ticks and rodents from northwestern China. Appl Environ Microbiol 67, 5161-5165.

Thompson, J. D., Gibson, T. J., Plewniak, F., Jeanmougin, F. \& Higgins,
D. G. (1997). The CLUSTAL_X windows interface: flexible strategies for multiple sequence alignment aided by quality analysis tools. Nucleic Acids Res 25, 4876-4882.

Wang, G., van Dam, A. P., Le Fleche, A., Postic, D., Peter, O., Baranton, G., de Boer, R., Spanjaard, L. \& Dankert, J. (1997). Genetic and phenotypic analysis of Borrelia valaisiana sp. nov. (Borrelia genomic groups VS116 and M19). Int J Syst Bacteriol 47, 926-932.

Wang, G., van Dam, A. P., Schwartz, I. \& Dankert, J. (1999). Molecular typing of Borrelia burgdorferi sensu lato: taxonomic, epidemiological, and clinical implications. Clin Microbiol Rev 12, 633-653.

Yanagihara, Y. \& Masuzawa, T. (1997). Lyme disease (Lyme borreliosis). FEMS Immunol Med Microbiol 18, 249-261.

Younsi, H., Postic, D., Baranton, G. \& Bouattour, A. (2001). High prevalence of Borrelia lusitaniae in Ixodes ricinus ticks in Tunisia. Eur J Epidemiol 17, 53-56.

Zhioua, E., Bouattour, A., Hu, C. M., Gharbi, M., Aeschliman, A., Ginsberg, H. S. \& Gern, L. (1999). Infection of Ixodes ricinus (Acari: Ixodidae) by Borrelia burgdorferi sensu lato in North Africa. J Med Entomol 36, 216-218. 